\title{
Energy consumption and analysis of industrial drying plants for fresh pasta process
}

\author{
Lucio Brunetti, Ferruccio Giametta, Pasquale Catalano, Francesco Villani, \\ Jonathan Fioralba, Flavio Fucci, Giovanna La Fianza \\ Department of Agriculture, Environment and Food Science, University of Molise,
Campobasso, Italy
}

\begin{abstract}
The article presents results concerning the energy needs and the $\mathrm{CO}_{2}$ emissions resulting from the production process of a small factory (located in Molise region) producing fresh pasta. Two production processes are responsible for the most of energy demand. The pasteurisation and the drying processes are responsible for the $50 \%$ of the electricity consumption and the whole thermal energy. Therefore innovative solutions have been studied in order to limit the energy requirements and the $\mathrm{CO}_{2}$ emissions. Such solutions take into account the adoption of high-efficiency motors and heat recovery in the main processes.
\end{abstract}

\section{Introduction}

The technologies for the production of pasta evolved since 70's and 80 's of the last century and deep changes of the structure and organisation of the modern pasta factory occurred.

Deeper innovation regarded the production of fresh and therefore perishable pasta (moist pasta). During the 1980-1990 decade the demand of fresh pasta packaged in modified atmosphere increased and the pasta factories were not ready yet to face the new market. Moreover, the introduction of HACCP standard and the new approach to the cleaning management and food safety problems, determined the need to replace some of the old machines with new and advanced technologies and the increasing of large-scale production of fresh pasta.

Correspondence: Ferruccio Giametta, Department of Agriculture, Environment and Food Science, University of Molise, via De Sanctis, 86100 Campobasso, Italy.

E-mail: ferruccio.giametta@unimol.it

Key words: Pasta; plant; energy; heat; drying.

Received for publication: 27 May 2015.

Accepted for publication: 4 July 2015.

(C) Copyright L. Brunetti et al., 2015

Licensee PAGEPress, Italy

Journal of Agricultural Engineering 2015; XLVI:478

doi:10.4081/jae.2015.478

This article is distributed under the terms of the Creative Commons Attribution Noncommercial License (by-nc 3.0) which permits any noncommercial use, distribution, and reproduction in any medium, provided the original author(s) and source are credited.
The plants upgrade increased efficiency by enhancing the energy saving and the environmental protection.

Drying is a process that requires high-energy input because of the high latent heat of water evaporation and relatively low energy efficiency of industrial dryers. It is reported that industrial dryers consume about $12 \%$ of the total energy used in manufacturing processes (Bahu, 1991) and the drying cost may rise to $60-70 \%$ of the total cost (Bahu, 1991). Discussions on the performance, energy consumptions, energy savings, automations, drying quality, and design of industrial drying systems and optimisation methods used to improve system output are discussed in detail in literature (Khanna and Singh, 1967; Botteril, 1975; Keey, 1978; Mujumdar, 1987; Holmes et al., 1988; Kiranoudis et al., 1996; Moraitis and Akritidis, 1996; Hills et al., 1997; Bray and Prat, 1999; Feng et al., 2001; Guler et al., 2002; Sahin and Dincer, 2002; Zou and Rolf, 2002; Migliori et al., 2005; Sheehan et al., 2005).

During fresh pasta production, the processes responsible for most of the energy consumption are essentially two: i) pasteurisation that uses about the $35 \%$ of the total electricity of the factory and nearly $78 \%$ of thermal energy (The thermal energy consumption is due to the burner, which determines the evaporation of water needed for pasteurisation allowing the right degree of pasta moisture); ii) drying that uses $10 \%$ of the total electricity and almost $22 \%$ of the thermal energy needs (The electricity consumption is due to the engine air intake and engine-powered fans to create airflow for drying. Thermal energy consumption is due to the boiler). All the measures concerning the requested and absorbed electrical power are manually tested by the use of anemometer. Therefore, energy analysis may allow designing more efficient thermal systems by removing or at least reducing the existing inefficiencies. Energy analysis becomes more crucial, especially for the industrial high-temperature drying applications (Dincer and Sahin, 2004).

In the literature, energy studies mainly deal with thermodynamic aspects of drying systems in large-scale industrial production (e.g., Topic, 1995; Dincer, 2002; Dincer and Sahin, 2004). However, evaluations of the energy efficiencies of small-scale pasta industries has recently appeared in the literature too.

The aim of the present research is to study small industrial pasta processing for analysis assessment and evaluation purposes.

\section{Materials and methods}

The study was carried out in a small factory (located in Molise region - Italy), which produces different shapes of fresh pasta.

The production process consists of 5 main stages (Figure 1): i) Picking up and storage of the raw material; ii) Mixing of ingredients: A kneader, equipped with a bladed shaft connected to a motor mixes the components; iii) Shaping (short pasta) or sheeting and cutting (long 
pasta) (Figures 2 and 3): Short pasta is produced by dropping the dough, containing about $35 \%$ moisture, in white food plastic tanks and then progressively loaded in the cutting-machine receiver. The production of long pasta is different due to the presence of the sheeting intermediate step; iv) Pasteurisation and pre-drying of pasta: The pasteurisation process is used to kill off a possible microbial contamination and to preserve the product from the attack of adulterating agents. The process occurs at a temperature of $97^{\circ} \mathrm{C}$. The pasteuriser consists of a steel strip entering an insulated room where the pasteurisation takes place. Pasta pre-drying is performed by 3 quartz lamps and 2 fans located on the final part of the pasteuriser which loads the product on wood looms; v) Drying: The wood loom is placed on a wheeled board. The board contains pasta with $29-30 \%$ of moisture. The board enters a drying cabinet kept at a temperature of $45^{\circ} \mathrm{C}$ to reach a moisture value lower than $25 \%$ to obtain the fresh pasta: the residence time in the

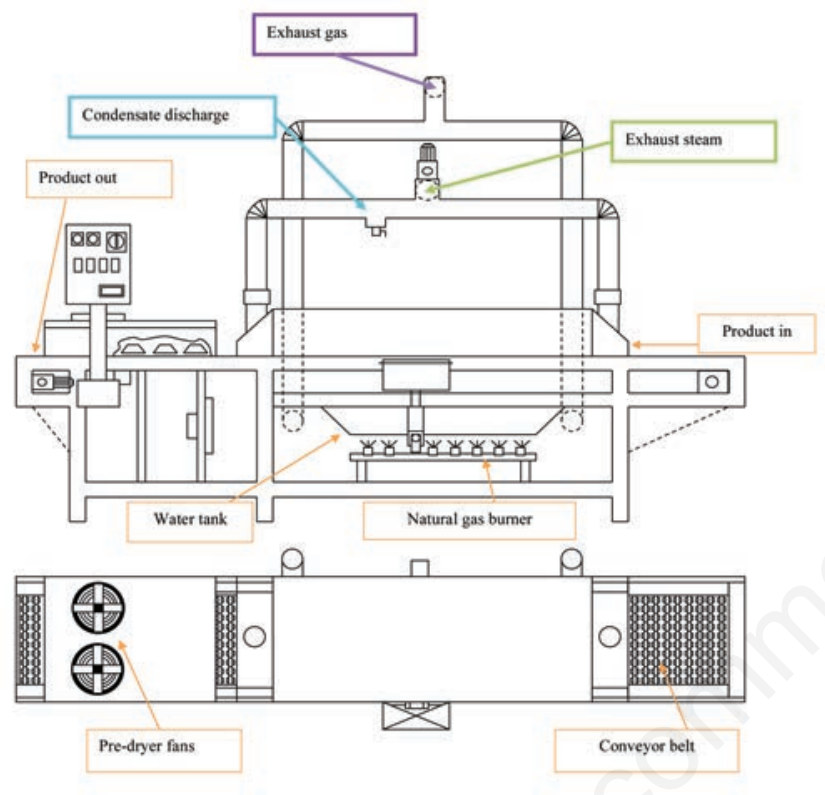

Figure 1. Production process.

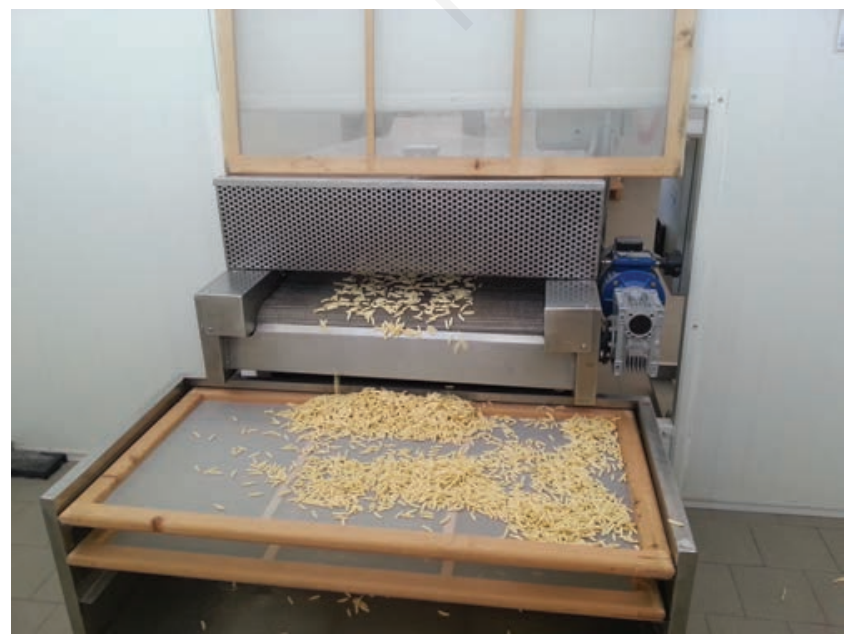

Figure 2. Full view of the plant. drier is one hour. The fresh pasta must stay in the drier at least $6-11 \mathrm{~h}$ to reach moisture value lower than $11 \%$ (the highest value permitted by the Italian legislation) to obtain the dried pasta. The dried pasta production is lower comparing to the fresh one. At the drier outlet, the pasta is conditioned for 4-5 min to have a thermal drop till a value of $15 / 16^{\circ} \mathrm{C}$. This process avoids the condensation inside the envelopes during the packaging and mould growth, too. Then the pasta is weighted and stored in controlled atmosphere packages $\left(50 \% \mathrm{CO}_{2}\right.$ and $50 \%$ $\mathrm{N}_{2}$ ). The storage takes places at a temperature of $4^{\circ} \mathrm{C}$ where the packed product remains till the delivery (usually a few days).

The different uses of the energy resources (electric energy, thermal energy, water), depending on the kind of process, are shown in Table 1.

The electric energy is used in the whole plant, e.g. lighting and electronic devices. The thermal energy is used in the pasteuriser and in the dryer. The first one uses directly natural gas to feed the boilers (nomi-

Table 1. Energy resources.

\begin{tabular}{lcc}
\hline Electrical energy & Thermal energy & Water \\
Dough & Pasteurisation & Dough \\
Sheeting & Drying (boiler) & Pasteurisation \\
\hline Cutting & & Drying \\
Shaping & \\
\hline Pasteurisation & \\
Drying & \\
\hline Packaging & \\
Storage & \\
\hline
\end{tabular}

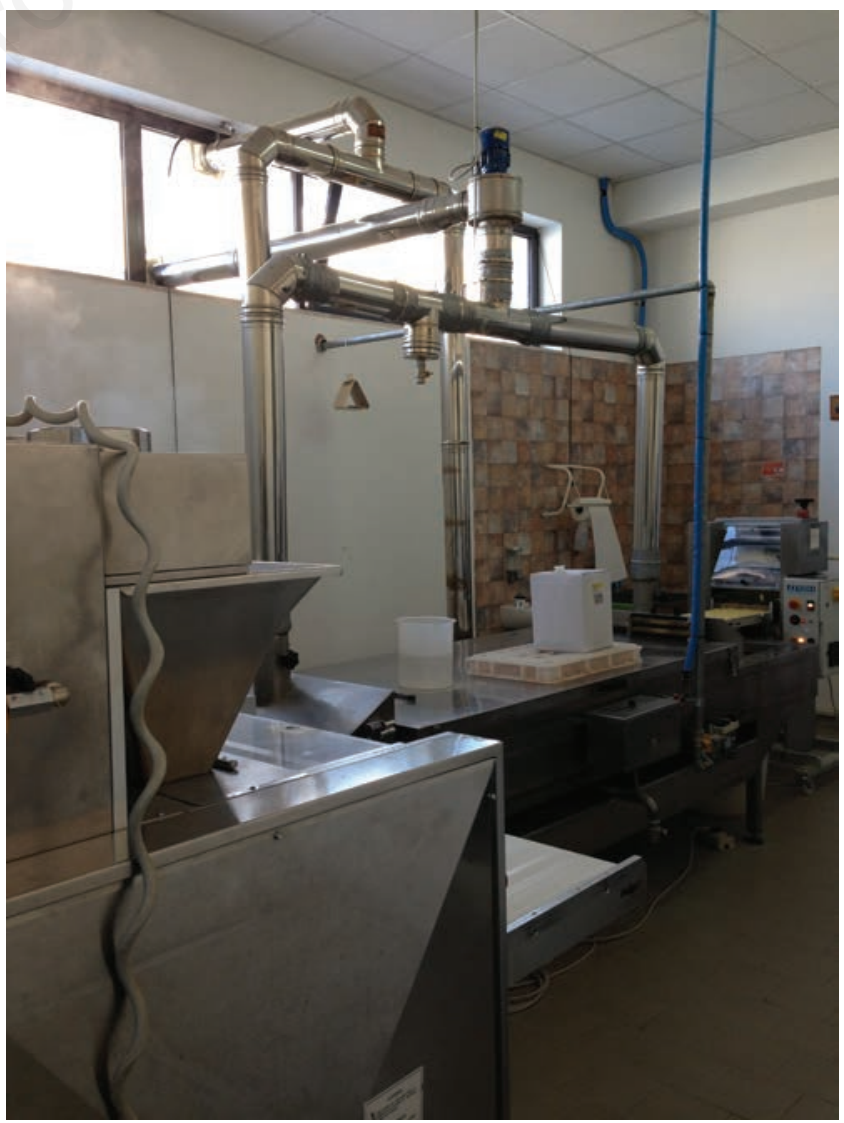

Figure 3. Output of dry pasta. 
nal power $35 \mathrm{~kW}$ for short pasta; nominal power $4.5 \mathrm{~kW}$ for the long pasta). The dryer needs hot water that, through coils located on the top of the cabinet, heats the drying airflow. The hot water is produced by a methane boiler (nominal power $24 \mathrm{~kW}$ ). The thermal and electrical powers of the equipment, taking into account the nominal energy needs, are shown in Table 2.

\section{Results}

The electrical and thermal energy consumptions were evaluated considering the real medium powers and working times (Table 3).

Pasteurisation is the process responsible of the most energy consumption: an energy balance was carried out in order to determine energy loss in the environment (mainly steam waste) and to make possible the reuse of latent heat of steam waste.

The water vapour needed for pasteurisation passes through the product pasteurising it.

Every hour $47 \mathrm{~kg}$ of water at temperature of $10^{\circ} \mathrm{C}$ enters the pasteuriser and an amount of $124,000 \mathrm{~kJ} / \mathrm{h}$ of thermal energy is needed to obtain saturated vapour at a temperature of $100^{\circ} \mathrm{C}$ :

$\mathrm{Q} / \mathrm{h}=\left[\left(\mathrm{cpH} 2 \mathrm{O}^{*} \mathrm{mH} 2 \mathrm{O}^{*} \Delta \mathrm{T}\right)+\left(\lambda \mathrm{H} 20^{*} \mathrm{mH} 20\right)\right] / \mathrm{h}=\left[\left(4.187 \mathrm{~kJ} / \mathrm{kgK}{ }^{*} 47\right.\right.$ $\left.\left.\mathrm{kg}^{*} 90 \mathrm{~K}\right)+(2257 \mathrm{~kJ} / \mathrm{kgK} * 47 \mathrm{~kg})\right] / \mathrm{h}=124000 \mathrm{~kJ} / \mathrm{h}=12.4^{*} 104 \mathrm{~kJ} / \mathrm{h}$.

The pasta $(50 \mathrm{~kg} / \mathrm{h})$, before pasteurisation, has a temperature of $25^{\circ} \mathrm{C}$ and a moisture of $32.5 \%$. The pasteurised pasta $(51.65 \mathrm{~kg} / \mathrm{h})$ has a temperature of $78^{\circ} \mathrm{C}\left(\Delta \mathrm{T}=53^{\circ} \mathrm{C}\right)$ and a moisture of $35.8 \%(\Delta \mathrm{RH}=$ $3.3 \%)$.

Therefore the amount of thermal energy required to pasteurise 50 $\mathrm{kg} / \mathrm{h}$ of pasta is $10,358 \mathrm{~kJ} / \mathrm{h}(2.88 \mathrm{~kW})$ and the energy supply consists of two components:

i) latent heat of condensation:
$\mathrm{Q} / \mathrm{h}=\left(\lambda_{\mathrm{H} 20}{ }^{*} \mathrm{~m}_{\mathrm{H} 20}\right) / \mathrm{h}=\left(2257 \mathrm{~kJ} / \mathrm{kg}^{*} 1.65 \mathrm{~kg}\right) / \mathrm{h}=3724 \mathrm{~kJ} / \mathrm{h}=1.03 \mathrm{~kW}$.

ii) sensible heat needed to raise the temperature of $50 \mathrm{~kg}$ of pasta from $25^{\circ} \mathrm{C}$ to $78^{\circ} \mathrm{C}$ in one hour:

$\mathrm{Q} / \mathrm{h}=\left(\mathrm{cp}_{\text {pasta }}{ }^{*} \mathrm{~m} * \Delta \mathrm{T}\right) / \mathrm{h}=\left(2.485 \mathrm{~kJ} / \mathrm{kgK}^{*} 50 \mathrm{~kg}^{*} 53 \mathrm{~K}\right) / \mathrm{h}=6585 \mathrm{~kJ} / \mathrm{h}=$ $1.83 \mathrm{~kW}$.

The value of the $\mathrm{Cp}_{\text {pasta }}$ is checked through the Heldman and Singh (Heldman and Sing, 2013) formula:

$\mathrm{Cp}_{\text {pasta }}=(1.424 \mathrm{Xc}+1.549 \mathrm{Xp}+0.675 \mathrm{Xf}+0.837 \mathrm{Xa}+4.187 \mathrm{Xw}) \mathrm{kJ} / \mathrm{kgK}$

Table 2. Thermal and electrical powers of the equipment.

\begin{tabular}{lcc}
\hline Equipment & $\begin{array}{c}\text { Nominal power } \\
\text { (electrical) }\end{array}$ & $\begin{array}{c}\text { Nominal power } \\
\text { (thermal) }\end{array}$ \\
Mixer & $1.6 \mathrm{~kW}$ & - \\
Baresina shaper & $2 \mathrm{~kW}$ & - \\
\hline Wireworker cutter & $3.7 \mathrm{~kW}$ & - \\
Sheet-cutter & $1 \mathrm{~kW}$ & - \\
\hline Sheet-roller & $0.2 \mathrm{~kW}$ & - \\
Pasteuriser & $4.5 \mathrm{~kW}$ & $35 \mathrm{~kW}$ \\
\hline Drying cabinet & $1.8 \mathrm{~kW}$ & - \\
Boiler & - & $24 \mathrm{~kW}$ \\
\hline Compressor refrigerating system & $2.55 \mathrm{~kW}$ & - \\
Condenser refrigerating system & $2 \times 0.252 \mathrm{~kW}$ & - \\
\hline Fans refrigerating system & $3 \times 0.150 \mathrm{~kW}$ & - \\
Compressor & $4 \mathrm{~kW}$ & - \\
\hline Lighting & $13 \mathrm{x} 0.072 \mathrm{~kW}$ & - \\
\hline
\end{tabular}

Table 3. Thermal and electrical energy consumption of the equipment.

\begin{tabular}{|c|c|c|c|c|c|c|c|c|}
\hline \multirow[t]{2}{*}{ Equipment } & \multirow{2}{*}{$\begin{array}{l}\text { Real medium power } \\
(\mathrm{kW})\end{array}$} & \multirow{2}{*}{$\begin{array}{l}\text { Working } \\
\text { h/month }\end{array}$} & \multicolumn{3}{|c|}{ Mean hourly consumption } & \multicolumn{3}{|c|}{ Mean monthly consumption } \\
\hline & & & $\begin{array}{c}\text { Electrical } \\
\text { energy } \\
\text { (kWh) }\end{array}$ & $\begin{array}{c}\text { Methane } \\
\text { gas } \\
\text { (kWh) }\end{array}$ & $\begin{array}{l}\text { Water } \\
(\mathrm{kg})\end{array}$ & $\begin{array}{c}\text { Electrical } \\
\text { energy } \\
\text { (kWh) }\end{array}$ & $\begin{array}{c}\text { Methane } \\
\text { gas } \\
\text { (kWh) }\end{array}$ & $\begin{array}{l}\text { Water } \\
\text { (kg) }\end{array}$ \\
\hline Mixer & 1.3 & 81 & 1.3 & - & 10 & 105.3 & - & 820 \\
\hline Baresina & 1.2 & 85 & 1.2 & - & - & 102 & - & - \\
\hline Sheeter & 1.9 & 32 & 1.8 & - & - & 60.8 & - & - \\
\hline Sheet-cutter & 0.6 & 27 & 0.6 & - & - & 16.2 & - & - \\
\hline Sheet-roller & - & 32 & - & - & - & - & - & - \\
\hline Pasteuriser & 2.7 & 140 & 2.7 & 34.41 & 47 & 378 & 4817.4 & 7050 \\
\hline Drying cabinet & 0.8 & 136 & 0.8 & 10.4 & - & 108.8 & 1414.4 & - \\
\hline Packer & 1.1 & 56 & 1.1 & - & - & 61.6 & - & - \\
\hline Freezer compressor & 2.55 & 40 & 2.55 & - & - & 63.7 & - & - \\
\hline Condenser fans & $2 \times 0.252$ & 40 & 0.54 & - & - & 12.6 & - & - \\
\hline Evaporator fans & $3 \times 0.150$ & 40 & 0.45 & - & - & 11.2 & - & - \\
\hline Air compressor & 4 & 20 & 4 & - & - & 80 & - & - \\
\hline Lighting & $13 \times 0.072$ & 90 & - & - & - & 83.5 & - & - \\
\hline Total & 18.04 & - & - & - & - & 1084 & 6231.8 & 7870 \\
\hline
\end{tabular}


where:

$\mathrm{Xc}$ is the carbohydrate fraction;

$\mathrm{Xp}$ is the protein fraction;

$\mathrm{Xf}$ is the fats fraction;

$\mathrm{Xa}$ is the ash fraction;

$\mathrm{Xw}$ is the water fraction.

A specific value of $2.485 \mathrm{~kJ} / \mathrm{kgK}$ is obtained for fresh pasta and a specific value of $2.531 \mathrm{~kJ} / \mathrm{kgK}$ for dry pasta (Table 4 ).

The specific heat of long-egg pasta is the same of the short fresh pasta and its production rate is $1 / 3$ of the total one.

In the energy analysis of the fresh pasta production the $\mathrm{CO}_{2}$ emission in the environment is also taken into account.

The monthly pasta production consists of $5846 \mathrm{~kg}$ of pasta, $175 \mathrm{~kg}$ of which is dry pasta. In this period the amount of used energy is the following: i) $1100 \mathrm{kWh}$ of electricity, $44.77 \mathrm{kWh}$ of which used for dry pasta; ii) $6231.8 \mathrm{kWh}$ of thermal energy, $366.2 \mathrm{kWh}$ used for production of dry pasta.

Every kg of monthly produced pasta requires: i) $0.18 \mathrm{kWh}$ of electricity, equivalent to almost $78 \mathrm{~g}$ of $\mathrm{CO}_{2}$ emissions; ii) $1.1 \mathrm{kWh}$ thermal energy equivalent to almost $220 \mathrm{~g}$ of $\mathrm{CO}_{2}$ emissions.

The energy flow diagram of the system is shown in Figure 4.

Less than $10 \%$ of the total thermal energy is absorbed by the product during the pasteurisation process. The remaining $90 \%$ is essentially used to kill off the microbial attack and to extend the product shelf-life. Anyway this high amount of energy is mainly eliminated as saturated vapour and wasted in the environment. This case study is typical of a common existing situation in small pasta making factories.

Table 4. Fractions of component in different kind of pasta (Heldman and Sing, 2013).

\begin{tabular}{lcc}
\hline Fraction & Fresh short pasta & Long pasta/egg \\
Xc (carbohydrates) & 0.626 & 0.623 \\
Xp (protein) & 0.105 & 0.105 \\
\hline Xf (fats) & - & 0.030 \\
Xa (ash) & 0.085 & 0.085 \\
\hline Xw (water) & 0.325 & 0.325 \\
\hline
\end{tabular}

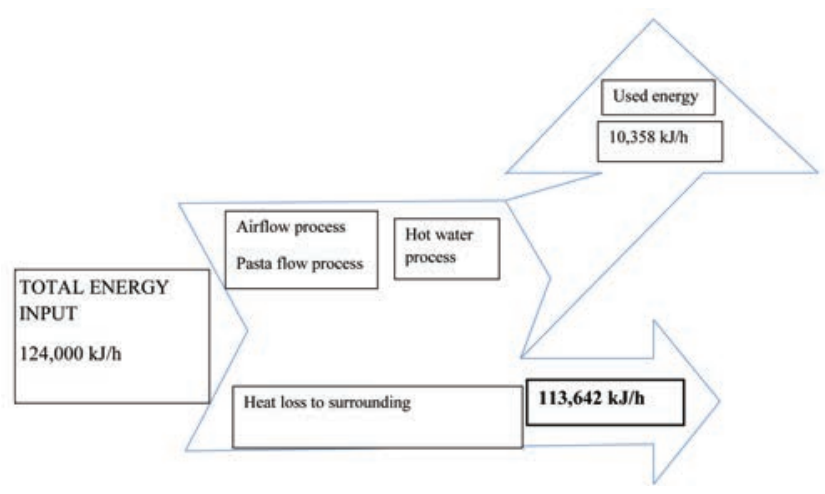

Figure 4. Energy flow diagram of the system (given as a percentage of the whole energy input).

\section{Conclusions}

In the present study in-plant control measures were focused on saving energy consumption of a small factory producing fresh pasta, reducing raw materials losses and reducing the volume of the discharged effluent.

The following measures were implemented to reduce the energy consumption: i) insulating steam lines; ii) installing steam traps; iii) repairing or replacing steam valves; iv) maximising boilers efficiency; v) installing pressure regulators on steam lines.

In-plant control measures such as installation of water flow meters, spring valves on water hoses and design of a steam condensate recovery system proved to be very efficient means in reducing water and energy consumption throughout the pasta factory in addition to the reduction of the hydraulic load on the wastewater treatment plant. As discussed in current literature, cost benefit analysis for the implemented environmental improvements had proved to be very inexpensive with a short payback period and resulted in great savings, although it has rarely been applied to the optimisation of small pasta factories.

Pasta industry should improve in-plant control (e.g., energy saving, water saving, less-polluting technologies) in order to achieve modernisation and decentralisation of facilities to ease the pollution burden on urban centres.

\section{References}

Bahu R.E. 1991. Energy consumption in dryer design. In: A.S. Mujumdar and I. Filkova (eds.), Drying '91. Elsevier, Amsterdam, the Netherlands, pp 553-557.

Bianchi B., Catalano P., Gentile A., Giametta F., La Fianza G. Microclimate measuring and fluid dynamic simulation in an industrial broiler house: testing of an experimental ventilation system. Veterinaria Italiana. 2015;51:85-92.

Botteril J.S.M. 1975. Fluid bed heat transfer. Academic Press, London, UK.

Bray Y.L., Prat M. 1999. Three dimensional pore network simulation of drying in capillary porous media. Int. J. Heat Mass Transf. 42:4207-24.

Dincer I. 2002. On energetic, exergetic and environmental aspects of drying systems. Int. J. Energy Res. 26:717-27.

Dincer I., Sahin A.Z. 2004. A new model for thermodynamic analysis of a drying process, Int. J. Heat Mass Transfer. 47:645-52.

Feng H., Tang J., Cavalieri R.P., Plumb 0.A. 2001. Heat and mass transport in microwave drying in porous materials ia a spouted bed. AIChE J. 47:645-52.

Guler S., Koksel H., Ng PKW. 2002. Effect of industrial pasta drying temperatures on starch properties and pasta quality. Food Res. Int. 35:421-7.

Hills B.P., Godward J., Wright K.M. 1997. Fast radial NMR microimaging studies of pasta drying, J. Food Eng. 33:321-35.

Heldman D., Sing P.R. 2013. Introduction to food engineering. Academic Press Ed., London, UK.

Holmes B.A., Hedman B.A., Salama S.Y. 1988. Overview of industrial drying needs and compenting technologies. Plant Operat. Progr. 7:199-203.

Keey R.B. 1978. Introduction to industrial drying operations. Pergamon Press, New York, NY, USA.

Khanna M.L., Singh N.M., 1967. Industrial solar drying. Solar Ener. 11:87-9.

Kiranoudis C.T., Maroulis Z.B., Marinos-Kouris D. 1996. Design and operation of convective industrial dryers. AIChE J. 42:3030-40. 
Migliori M., Gabriele D., Cindio B., Pollini C.M. 2005. Modelling of high quality pasta drying: mathematical model and validation. J. Food Eng. 69:387-97.

Moraitis C.S., Akritidis C.B. 1996. Energy saving in industrial drying plants by partial recovery of the latent head of the exhaust air. In: A.S. Mujumdar et al. (eds.), Drying '96 (Proc. Int. Drying Symp.). Department of Process and Environmental Engineering, Lodx Technical University, Lodz, Poland, 10:A.489-496.

Mujumdar A.S. 1987. Handbook of industrial drying, Marcel Dekker, New York, NY, USA.

Sahin A.Z., Dincer I. 2002. Graphical determination of drying process and moisture transfer parameters for solids drying. Int. J. Heat Mass Transf. 45:3267-73.

Sheehan M.E., Britton P.E., Schneider P.A. 2005. A model for solid transport in flighted rotary dryers based on physical considerations. Chem. Engine. Sci. 60:4171-82.

Topic R. 1995. Mathematical model for exergy analysis of drying plants. Drying Technol. 13:437-45.

Zou S., Rolf R. 2002. A model for high pressure vaporization droplets of complex liquid mixture using coninuious thermodynamics. Int. J. Heat Mass Transfer. 45:495-567. 